\title{
Farm systems analysis of two thistles of differing seasonal pasture growth impacts in North Island hill country
}

\author{
David R. STEVENS ${ }^{1}$, Katherine N. TOZER ${ }^{2}$, Tim RHODES ${ }^{3}$, Sue M. ZYDENBOS ${ }^{4}$, Robyn A. DYNES ${ }^{4}$, \\ Michael J. MANNING ${ }^{5}$, Ants H.C. ROBERTS ${ }^{5}$, Michael WHITE ${ }^{5}$ and Alister METHERELL ${ }^{5}$ \\ ${ }^{1}$ AgResearch Invermay, Private Bag 50034 Mosgiel, New Zealand \\ ${ }^{2}$ AgResearch Ruakura, Private Bag 3123, Hamilton, New Zealand \\ ${ }^{3}$ Wi Pere Trust, Tangihanga Station, Gisborne, New Zealand \\ ${ }^{4}$ AgResearch Lincoln, Private Bag 4749, Christchurch, New Zealand \\ ${ }^{5}$ Ravensdown Ltd, PO Box 1049, Christchurch, New Zealand \\ david.stevens@agresearch.co.nz
}

\begin{abstract}
Models for infestations of Californian thistle (Cirsium arvense) and variegated thistle (Silybum marianum) were used to modify fortnightly pasture growth forecasts using Agricultural Production Systems simulator software using climate and soil data from a single farm (Tangihanga Station) over four aspects and three slope classes. Modelling using Farmax software was used to estimate profitability using the current farm enterprises with or without either the Californian or variegated thistles. Modelled pasture production, based on field observations of thistle infestation, was similar to estimates using animal intake (from Farmax). Californian thistle reduced pasture production in summer and autumn, while variegated thistle reduced autumn, winter and spring pasture growth. Californian thistle had a much greater overall presence $(20 \%)$ than variegated thistle $(9 \%)$. Both types of thistle reduced the potential to finish lambs in summer and reduced ewe wintering numbers, while the presence of Californian thistles also reduced over-wintering cattle numbers, by reducing summer-autumn pasture accumulation. Cost of control for Californian thistle ( $\$ 233 / \mathrm{ha}$ ) over two years was higher than for variegated thistle ( $\$ 184 / \mathrm{ha})$ over four years. Net profitability was reduced by $24 \%$ ( $\$ 87 / \mathrm{ha}$ ) by the presence of Californian thistle, and by $37 \%(\$ 135 / \mathrm{ha})$ by the presence of variegated thistle.
\end{abstract}

Keywords: annual, Cirsium arvense, pasture production, perennial, profitability, Silybum marianum

\section{Introduction}

Weed ingress can be a significant issue that restricts pasture production on farm. The type of weed can have a significant role in the scale and timing of that impact. For example, unpalatable weeds such as thistles compete for water and nutrients, take up physical space, and reduce the utilisation of pasture that may grow amongst the thistles. However, annual thistles present different challenges to perennial thistles. Annual thistles, such as variegated thistle (Silybum marianum), generally germinate in autumn, overwintering before flowering and setting seed in early summer (Shea \& Kelly 1998). This results in an impact on pasture production that increases from germination in autumn, to a peak in early summer. Subsequent pasture production may also be reduced due to the large areas of bare ground that are exposed after thistle die back. Seed can last in the ground for many years (James et al. 2010) and, therefore, control programmes are needed over significantly long time frames.

Perennial thistles, such as Californian thistle (Cirsium arvense), regenerate from a creeping root system and, therefore, have a different growth profile. They begin growth during spring and have a peak impact in late summer (Bourdôt et al. 2016). Their underground root reserve means that control measures may take several applications of chemical before completely depleting the resource to gain effective population control.

The impact of thistles is best expressed as the impact of either covering the soil surface and so preventing pasture growth, or by preventing access to any pasture that may grow within a patch of thistles. This impact on utilisation, characterised by Hartley and James (1979), is central to the Californian thistle impact model developed by Bourdôt et al. (2016). In both these cases, the area occupied by thistles prevents utilisation of pasture in that area. When this is scaled to a wholefarm level, it can be represented as a loss of pasture, or a suppression of net growth per hectare.

The establishment of thistle populations depends on a range of factors including adjacent competition for light, nutrient supply, moisture availability and temperature (Shea et al. 2006). This means that the impact of thistles will vary across a landscape, depending on the state of the current vegetation, soil characteristics such as fertility and moisture retention, and topography and aspect, as these will affect soil temperature and moisture. Therefore, whole-farm impacts of thistles cannot be fully understood without applying these principles to the landscapes that occur within a farm. 
Geographical information systems (GIS) provide a mechanism to define the landscape units within a farm. These can be coupled with detailed soil information to provide a framework to predict the relative establishment success and growth of thistles and, therefore, calculate the impact on pasture growth at the landscape level within the farm. Coupling the GIS and soil data with thistle growth models and then with whole-farm modelling can provide insight into the potential of thistle infestation on farm system design and profitability.

A case-study approach was used to investigate the use of these data sources to determine the relative impacts of annual and perennial thistles on the productivity and profitability of one Gisborne farm, Tangihanga Station.

\section{Methods}

A case study to investigate the relative advantage of using precision farming techniques was initiated with the Wi Pere Trust (Gisborne), in conjunction with Ravensdown Ltd and AgResearch Ltd. This programme identified the on-farm issues that were potentially restricting profitability and explored options to remove those obstacles. Improvement in weed control and management has been identified as a major opportunity to increase profitability, with weed control being a significant part of the annual budget. As part of the programme, the potential values of full control of thistles was investigated at the whole farm level. Both Californian thistle (Cirsium arvense) and variegated thistle (Silybum marianum) have been identified as having significant populations on the farm. This situation provided the opportunity to compare the impacts of annual or perennial thistles on whole-farm profitability. The development of predicted pasture growth profiles for the various slopes, aspects and soil fertility layers of the property, using the Agricultural Production Systems simulator (APSIM; Keating et al. 2003), provided the base data from which to model the impacts of thistles.

This work used the following approach: a baseline model was developed assuming no thistle infestation. Two thistle infestation models were then developed from this; a model with an infestation of Californian thistles, and a model with variegated thistle infestation. The relative productivity and profitability of these two models were compared, and the net value of controlling thistles to return to the baseline position was calculated.

A base non-infested browntop (Agrostis capillaris) pasture production profile was generated using a combination of GIS and soil fertility and climate data; this was modified using thistle infestation models for both perennial and annual thistles. Enterprises, based on current practice, were added and modified, and farm profitability was determined using the Farmax software
(Farmax, Hamilton, NZ). Thistle control options were developed and the benefits of thistle control estimated as a long-term capital investment. These processes are described in detail below. The current case study farm, Tangihanga Station, Gisborne (Lat. -38.5515 S, Long. 177.8814 E), had a significant infestation of both Californian and variegated thistle. Therefore, estimates of pasture production from current practices and stock requirements were not able to be used as a base, uninfested position.

\section{Pasture growth estimates}

Pasture growth estimates were modelled using the APSIM software (Keating et al. 2003) and used as a base for the modelling. Briefly, nine landscape units (LU) on Tangihanga Station were identified and mapped using GIS to provide the total area represented by each LU (Table 1). Pasture growth estimates were made using soil and climate data over the 2005 to 2014 period. The means of these values were used. The growth of browntop pasture was calculated at three Olsen $\mathrm{P}$ values both with and without white clover (Trifolium repens). The final data set used was at an Olsen $\mathrm{P}$ of 10 , reflecting current soil fertility status. Pasture production either with or without white clover was similar at this phosphate level.

\section{Predicting the impact of thistle control}

The impacts of Californian thistle on ground cover and, therefore, potential pasture growth have been quantified from the model produced by Bourdôt et al. (2016). The pattern of impact throughout the year is depicted in Figure 1. Peak impact is in mid-February.

There was no equivalent model for variegated thistle. Therefore, germination and growth models were developed from data presented by Montemurro et al.

Table 1 Landscape units identified using GIS at Tangihanga Station

\begin{tabular}{lll}
\hline Aspect & Slope & $\begin{array}{c}\text { Effective Area } \\
\text { (ha) }\end{array}$ \\
\hline North & Easy $0-15^{\circ}$ & 124 \\
& Moderate $15-25^{\circ}$ & 217 \\
& Steep $>25^{\circ}$ & 158 \\
\hline East/West & Easy 0-15 & 78 \\
& Moderate $15-25^{\circ}$ & 143 \\
& Steep $>25^{\circ}$ & 113 \\
\hline South & Easy 0-15 & 152 \\
& Moderate $15-25^{\circ}$ & 241 \\
& Steep $>25^{\circ}$ & 214 \\
\hline Total & & 1440 \\
\hline
\end{tabular}




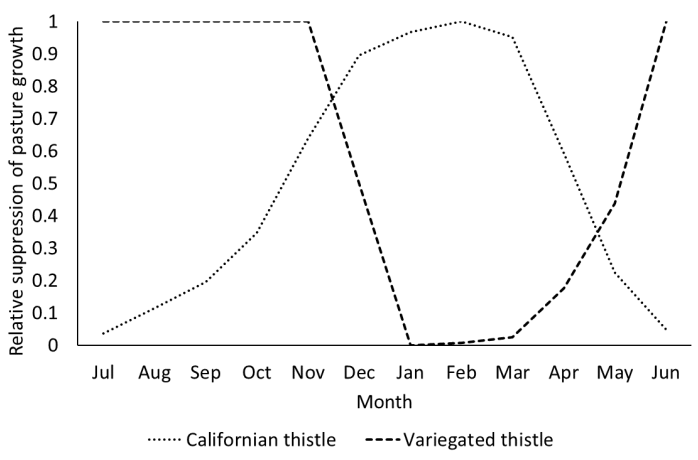

Figure 1 The pattern of pasture production suppression (1 = no pasture growth) by Californian and variegated thistle within a thistle patch throughout the year.

(2007) and Parmoon et al. (2015). These models then used local climatic data to predict the germination and growth of thistles to develop a potential proxy for ground cover and, therefore, pasture growth suppression within the thistle patch (Figure 1).

Observation confirmed that the presence of Californian thistles was greatest on South aspects, intermediate on East aspects and least on North aspects. Infestation rates of 30, 20 and $10 \%$ were chosen for the South, East and North aspects respectively. It was assumed that each slope class was affected equally.

Variegated thistle infestation was based on observations in 2016/17 (Tozer et al. 2018), which found that infestation was 3\% on South aspects, $9 \%$ on East/West aspects and $15 \%$ on North aspects.

The chosen infestation rates were then combined with the potential pasture growth suppression models and applied separately to the APSIM pasture growth forecasts to create estimated pasture production under either Californian or variegated thistle infestations.

\section{Whole-farm modelling}

The economic value of controlling thistles was evaluated using the Farmax farm systems model (Farmax Pro (Science) version 6.5.3.17). This was used to fit enterprises to the pasture production estimates that arose from the APSIM modelling (Minus clover as a base) and the adjusted pasture production estimated after the fitting of the thistle models.

A base model was developed first to provide an estimate of potential profitability and productivity in a status quo, thistle-free environment. The current Tangihanga enterprises were used as a base but were modified for price to reflect average costs and product prices for North Island hill country, and to fit the APSIM pasture growth predictions. This then gave a standard scenario from which to estimate the relative value of controlling thistles.
Enterprises, stock performance and pasture production The Base model was built using the current enterprises and stock performance from the 2017 Tangihanga Station Farmax model. The station is 1440 ha, with a base stocking rate of $11.5 \mathrm{SU} / \mathrm{ha}$. Estimates of potential pasture growth were taken from the long-term Tangihanga Farmax model, which uses animal intake to predict pasture growth. These pasture growth estimates were based on pasture cover estimates from the 10-year period from 2006-2015 and adjusted to remove the effects of applied nitrogen fertiliser. The pasture growth estimates generated by APSIM (Figure 2) are generally higher than the current estimates from Farmax in late spring and summer. Low pasture production in the winter and early spring may be a reflection of low soil nitrogen levels due to the low clover content. Previous pasture growth measurement in this region over eight years (Gray et al. 1987) demonstrated a similar pasture growth profile throughout the year to the APSIM estimates, with similar winter pasture growth rates but higher spring and summer pasture growth rates. The site of Gray et al. (1987) had a higher summer rainfall, with similar Olsen P status. The estimates from Farmax represent the amount of pasture removed by the grazing animal. In this respect it reflects the apparent utilisation of pasture per hectare. In the current circumstances, this also represents a restriction of access to areas of the farm with significant thistle infestation. The modelling of the combined impacts of both Californian and variegated thistle infestation (Figure 2) are more closely aligned to the Farmax predictions in summer. The discrepancy in summer may be due to an overestimate of the recovery of pasture growth after dieback in variegated thistles (see Figure 1). The low prediction of pasture growth in April and May might reflect the conclusions of Hartley and James (1979) who suggested that more pasture grown within the patches was able to be utilised as

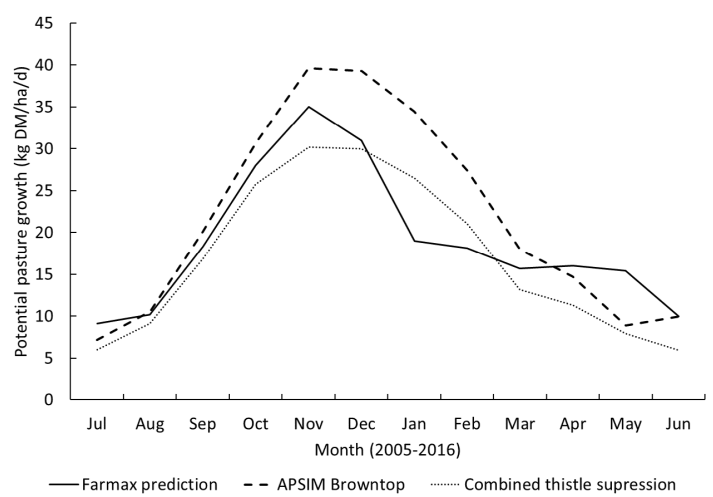

Figure 2 Comparison of the APSIM pasture growth estimates and the historical Tangihanga pasture growth records from Farmax, both averaged over the period 2005-2016. 
Californian thistle died back in the autumn. Therefore, the Bourdôt et al. (2016) model may overestimate the impacts of thistles in April and May.

\section{Financials}

The main source of farm costs used was standardised to be the Beef + Lamb NZ North Island hill country database (2016-17). This was adjusted to include the cost of nitrogen fertiliser, as used. Actual expenditure on feed, crops and grazing were also used (Table 2).
Prices for livestock in the Tangihanga Farmax model were used across all models. New purchases and sales were done using the standard Farmax prices schedules (2016-17).

\section{Stock policies}

The initial stock policies for the base model were based on the current Tangihanga stock policies. However, the use of the APSIM pasture growth estimates increased pasture availability in summer significantly. Therefore,

Table 2 General costs applied to the modelling.

\begin{tabular}{|c|c|c|c|c|}
\hline (\$/year) & & \$ Total & \$/ ha & \$/SU \\
\hline \multirow[t]{3}{*}{ Wages } & Wages & $98,414.00$ & 68.34 & 5.96 \\
\hline & Management Wages & $23,117.00$ & 16.05 & 1.40 \\
\hline & Total Wages & $121,531.00$ & 84.40 & 7.36 \\
\hline \multirow[t]{4}{*}{ Stock } & Animal Health & $83,718.00$ & 58.14 & 5.07 \\
\hline & Shearing & $70,673.00$ & 49.08 & 4.28 \\
\hline & Total Stock & $154,391.00$ & 107.22 & 9.35 \\
\hline & Total Feed/Crops/Grazing & & - & - \\
\hline \multirow[t]{6}{*}{ Fertiliser } & Fertiliser (Excl. N \& Lime) & $116,525.00$ & 80.92 & 7.06 \\
\hline & Nitrogen & \multicolumn{3}{|c|}{ Variable as per each model } \\
\hline & Lime & $10,843.00$ & 7.53 & 0.66 \\
\hline & Total Fertiliser & $315,009.00$ & 218.76 & 19.08 \\
\hline & Weed \& Pest Control & $19,973.00$ & 13.87 & 1.21 \\
\hline & Vehicle Expenses & $38,822.00$ & 26.96 & 2.35 \\
\hline Other Farm & Fuel & $24,682.00$ & 17.14 & 1.49 \\
\hline \multirow[t]{5}{*}{ Working Expenses } & Repairs \& Maintenance & $24,008.00$ & 86.12 & 7.51 \\
\hline & Freight \& Cartage & $20,310.00$ & 14.10 & 1.23 \\
\hline & Electricity & $14,531.00$ & 10.09 & $\$ 0.88$ \\
\hline & Other Expenses & - & - & - \\
\hline & Total Other Farm Working & $242,384.00$ & 168.32 & 14.68 \\
\hline \multirow[t]{6}{*}{ Standing charges } & Administration & $39,139.00$ & 27.18 & 2.37 \\
\hline & Insurance & $19,498.00$ & 13.54 & 1.18 \\
\hline & ACC Levies & $9,317.00$ & 6.47 & 0.56 \\
\hline & Rates & $40,478.00$ & 28.11 & 2.45 \\
\hline & Total Standing Charges & $108,432.00$ & 75.30 & 6.57 \\
\hline & Total Farm Working Expense & $941,747.00$ & 653.99 & 57.03 \\
\hline Depreciation & & $55,973.00$ & 38.87 & 3.39 \\
\hline Total Farm Expenses & & $997,720.00$ & 692.86 & 60.42 \\
\hline \multirow[t]{4}{*}{ Other } & Rent/Lease & $42,509.00$ & 29.52 & 2.57 \\
\hline & Interest & $144,907.00$ & 100.63 & 8.78 \\
\hline & Total Other Expenses & $187,416.00$ & 130.15 & 11.35 \\
\hline & Total Expenses & $1,185,136.00$ & 823.01 & 71.77 \\
\hline
\end{tabular}


current policies of selling all lambs store was replaced by a lamb finishing policy, and a summer lamb buying policy which added a further 3000 lambs. The present 5 -Year ewe policy of buying in ewes was replaced by retaining the 5-Year ewes from the flock, with all ewes sold at weaning and lambs retained for finishing.

\section{Costs of thistle management}

The control costs of variegated and Californian thistles were calculated from actual costs and commercial expert advice.

The control regime chosen for Californian thistles included two applications of chemical in each of two years for complete control. This would include an application of clopyralid $(300 \mathrm{~g} / \mathrm{L}$ a.i. $)$ at $1 \mathrm{~L} /$ ha followed by $2,4 \mathrm{D}(680 \mathrm{~g} / \mathrm{L} 2,4$-dichlorophenoxyacetic acid) at $4 \mathrm{~L} /$ ha in year 1 and two applications of 2,4D at $4 \mathrm{~L} / \mathrm{ha}$ in the second year on all East/West and South aspects. Areas of Californian thistle on the North aspects are controlled by intensive sheep grazing.

Control of variegated thistles needs to continue for at least 4 years to prevent recurrence. The spray plan developed here uses an early blanket spray of 2,4D at $2 \mathrm{~L} / \mathrm{ha}$ on all East/West and North aspects, and a targeted approach to $10 \%$ of the South aspects, due to the lower incidence on South aspects, and the potential to identify patches remotely. This reduces the cost of control on South aspects from $\$ 43,200$ to $\$ 6,120$. Further on-going targeted costs may exist to prevent re-

Table 3 Stock numbers chosen for the Base Tangihanga Farmax model, and adjustments made for the Californian thistle and variegated thistle model.

\begin{tabular}{|c|c|c|c|}
\hline & \multicolumn{3}{|c|}{ Model } \\
\hline Stock & Base & $\begin{array}{c}\text { Californian } \\
\text { thistle }\end{array}$ & $\begin{array}{c}\text { Variegated } \\
\text { thistle }\end{array}$ \\
\hline Lambing \% & 137 & 137 & 137 \\
\hline MA Ewes & 9306 & 8306 & 8306 \\
\hline 1-year ewe purchase & 0 & 1000 & 1000 \\
\hline Ewe hoggets purchased & 2360 & 2360 & 2360 \\
\hline Lambs born & 12295 & 12295 & 12295 \\
\hline Lambs purchased & 5300 & 0 & 0 \\
\hline Lambs sold prime & 17595 & 9575 & 9575 \\
\hline Lambs sold store & 0 & 2720 & 2720 \\
\hline Calves purchased (heifer) & 254 & 254 & 254 \\
\hline 1-Year Heifer & 252 & 252 & 252 \\
\hline 2-Year Heifer & 248 & 163 & 248 \\
\hline Calves purchased (steer) & 414 & 414 & 414 \\
\hline 1-Year Steer & 414 & 414 & 414 \\
\hline 2-Year Steer & 303 & 183 & 185 \\
\hline Cull cow purchase & 205 & 205 & 205 \\
\hline
\end{tabular}

invasion, but are considered to be part of an on-going weed control programme. Control costs are documented in Tables 4 and 5.

The identification of large patches of thistles using remote sensing technology may enable spraying to be more targeted thus reducing the potential spray areas significantly. Modelling of potential strategies based on specific identification would provide an insight to these potential reductions, and future modelling would be able to test the overall farm impacts.

\section{Results and Discussion \\ Pasture growth}

The individual impacts of Californian thistle and variegated thistle (Figure 1) on average whole-farm pasture growth is represented in Figure 3. Generally, infestation with Californian thistle reduced summer and autumn production, while infestation with variegated thistle reduced pasture production during winter and spring. Annual pasture production was $8030 \mathrm{~kg} \mathrm{DM} / \mathrm{ha}$ in the thistle-free model, which was reduced by 1090 $\mathrm{kg} \mathrm{DM} / \mathrm{ha}$ with Californian thistle infestation (13.5\%) and $430 \mathrm{~kg} \mathrm{DM} / \mathrm{ha}$ with variegated thistle infestation $(5.3 \%)$. The reduction in pasture production from Californian thistle is higher here than for the national estimate of $7.8 \%$ on sheep farms provided by Bourdot et al. (2016). The variegated thistle model assumed that pasture production resumes immediately after

Table 4 Costs of thistle control (\$/ha).

\begin{tabular}{|c|c|c|c|c|}
\hline & \multicolumn{2}{|c|}{ Californian thistle } & \multicolumn{2}{|c|}{ Variegated thistle } \\
\hline & $\begin{array}{c}\text { Treatment } 1 \\
\text { clopyralid/2,4D }\end{array}$ & $\begin{array}{c}\text { Treatment } 2 \\
2 \times 2,4 D\end{array}$ & $\begin{array}{c}\text { General } \\
2,4 D\end{array}$ & $\begin{array}{c}\text { Targeted } \\
2,4 \mathrm{D}\end{array}$ \\
\hline Chemical & 71 & 66 & $\$ 17$ & 17 \\
\hline Application & 55 & 55 & 55 & 85 \\
\hline Total & 181 & 176 & 72 & 102 \\
\hline
\end{tabular}

Table 5 Area treated and total costs for a control programme for Californian and variegated thistles.

\begin{tabular}{lcccc}
\hline & Year 1 & Year 2 & Year 3 & Year 4 \\
\hline $\begin{array}{l}\text { Californian } \\
\text { Full (ha) }\end{array}$ & 941 & 941 & & \\
Cost (\$) & 169,926 & 165,767 & & \\
Cost/ha farmed & 118 & 115 & & \\
\hline Variegated & & & & \\
General (ha) & 834 & 834 & 834 & 834 \\
Targeted (ha) & 60 & 60 & 60 & 60 \\
Total Cost (\$) & 66,168 & 66,168 & 66,168 & 66,168 \\
Cost/ha farmed & 46 & 46 & 46 & 46 \\
\hline
\end{tabular}




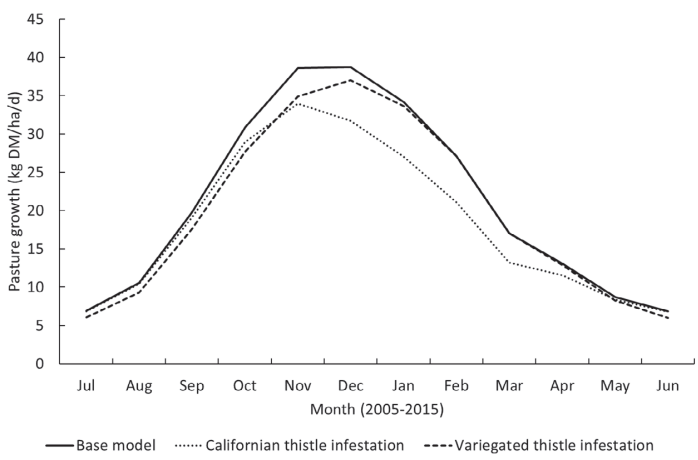

Figure 3 Net average whole-farm pasture production predicted with Californian thistle infestations of $30 \%, 20 \%$ and $10 \%$ of South, East/West and North aspects respectively, and variegated thistle infestations of 3, 9 and $15 \%$ of South, East/West and North aspects respectively, compared with a thistle-free pasture production curve.

thistles have died back post-flowering. This may not be the case and, therefore, the impacts of variegated thistle on pasture production may be greater than those demonstrated here and may be the effect illustrated in Figure 1 when comparing the pasture growth profile from Farmax with the thistle impacted growth.

\section{Changes in stock policy}

The following changes in stock policy and sales (Table 6) were used to balance the feed supply and demand when pasture production was affected by thistle growth (Figure 3). These policy changes were chosen by the authors as realistic changes in decision making. They may not represent the optimal solution.

Both Californian and variegated thistle infestation required a shift from summer lamb finishing to store lamb sales. This reflects the current stock policy at Tangihanga Station, which provides some validation of the impact of thistles. Both thistle types also require a shift from retaining the oldest cohort of ewes when pasture production is unaffected by thistle, to selling ewes early and buying back ewes in the winter, in line with current policies. Further changes to cattle finishing means that both heifers and steers are sold earlier, at lighter weights, to balance the feed supply and demand. While the thistle types affect pasture production at different times, the impacts of variegated thistle in spring, at a much lower infestation rate, have a greater impact on stock policies.

The pasture cover estimates from each model (Figure 4) show that the livestock enterprises chosen are utilising the pasture in approximately similar ways and are therefore comparable and sustainable.

The effect of Californian thistles, restricting summer and autumn pasture production, reduced total income by approximately $\$ 219,000$ (Table 7). The effect of variegated thistles, restricting winter and spring pasture production, reduced total income by approximately $\$ 236,000$ (Table 7). In this model pasture production was reduced by $13.5 \%$ by Californian thistle while total income declined by $22 \%$. Variegated thistle caused a $5.3 \%$ decline in total pasture production but saw total income decline by $32 \%$. Bourdôt et al. (2016) used a national model to estimate potential loss of income

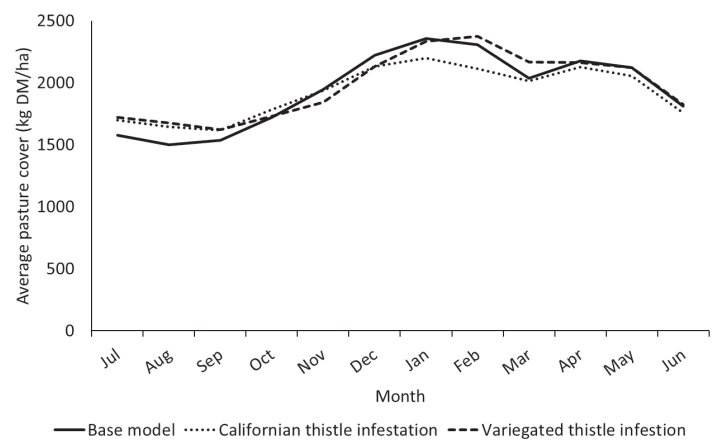

Figure 4 Pasture cover estimates for the base farm, and with either variegated thistle or Californian thistle infestation.

Table 6 Changes in stock policies induced by the changes in pasture production due to Californian or variegated thistle infestation.

\begin{tabular}{llll}
\hline & \multicolumn{1}{c}{ Model } \\
\cline { 2 - 4 } Stock policy & Base & Californian thistle & Variegated thistle \\
\hline Lamb purchase for finishing & 5300 & 0 & 0 \\
Store lamb sales & 0 & 2720 & 2720 \\
Ewe policy & Keep 1-year ewes & Sell 1000 April/Buy 1-year & Sell 1000 March/Buy 1-year \\
Steer finishing 1-year old & Sell 100 in April & Sell 220 in April & ewes in July \\
Steer finishing 2-year old & Sell 300 in October & Sell 180 in October & Sell 220 in April/Sell 120 in May \\
Heifer finishing & Sell 250 in July-Sep & Sell 90 in April/ rest in July-Sep & No change \\
Cull cow finishing & Buy Nov-Dec/Sell Mar & Buy Nov-Dec/Sell Mar & Buy Nov-Dec/Sell Feb \\
\hline
\end{tabular}


Table 7 A comparison of revenue and expenses for Tangihanga Station when pasture growth is affected by Californian or variegated thistle, or when thistles are controlled.

\begin{tabular}{|c|c|c|c|c|c|}
\hline & & & Base & Californian thistle & Variegated thistle \\
\hline \multirow[t]{6}{*}{ Revenue } & Sheep & Sales - Purchases & $1,009,970$ & 861,268 & 867,492 \\
\hline & & Wool & 231,451 & 212,122 & 212,122 \\
\hline & & Total & $1,241,420$ & $1,073,390$ & $1,079,614$ \\
\hline & Beef & Sales - Purchases & 432,948 & 381,993 & 358,251 \\
\hline & & Total & 432,948 & 381,993 & 358,251 \\
\hline & Total Revenue & & $1,674,369$ & $1,455,382$ & $1,437,865$ \\
\hline \multirow[t]{20}{*}{ Expenses } & Wages & Wages & 111,771 & 97,454 & 98,414 \\
\hline & & Management Wage & 26,255 & 22,892 & 23,117 \\
\hline & Stock & Animal Health & 95,080 & 82,902 & 83,718 \\
\hline & & Shearing & 80,265 & 69,984 & 70,673 \\
\hline & Fertiliser & Fertiliser (Excl. N \& Lime) & 116,525 & 116,525 & 116,525 \\
\hline & & Nitrogen & 156,191 & 145,186 & 187,641 \\
\hline & & Lime & 10,843 & 10,843 & 10,843 \\
\hline & Other Farm Working & Weed \& Pest Control & 19,973 & 19,973 & 19,973 \\
\hline & & Vehicle Expenses & 38,822 & 38,822 & 38,822 \\
\hline & & Fuel & 24,682 & 24,682 & 24,682 \\
\hline & & Repairs \& Maintenance & 140,839 & 122,799 & 124,008 \\
\hline & & Freight \& Cartage & 23,067 & 20,112 & 20,310 \\
\hline & & Electricity & 16,503 & 14,389 & 14,531 \\
\hline & Standing Charges & Administration Expenses & 39,139 & 39,139 & 39,139 \\
\hline & & Insurance & 19,498 & 19,498 & 19,498 \\
\hline & & ACC Levies & 9,317 & 9,317 & 9,317 \\
\hline & & Rates & 40,478 & 40,478 & 40,478 \\
\hline & Total Farm Working & pense & 969,305 & 895,053 & 941,747 \\
\hline & Depreciation & & 55,973 & 55,973 & 55,973 \\
\hline & Total Farm Expenses & & $1,025,278$ & 951,026 & 997,720 \\
\hline \multicolumn{3}{|c|}{ Economic Farm Surplus (EFS) } & 649,091 & 504,357 & 440,145 \\
\hline \multicolumn{3}{|c|}{ Economic Farm Surplus per ha } & 451 & 350 & 306 \\
\hline
\end{tabular}

from Californian thistle infestation in sheep and beef pastures. Average pasture production decline was $7.8 \%$, as was the predicted impact on total income.

Changes in stocking rate altered input variables, including a reduction of $\$ 9,000$ in nitrogen fertiliser expenditure. Final farm working expenses were reduced by approximately $\$ 74,000$ with Californian thistle infestation (Table 7). The infestation of variegated thistle was also accompanied by changes in stocking rate that reduced spending on nitrogen fertiliser by $\$ 31,000$, with final farm working expenses being reduced by approximately $\$ 28,000$ (Table 7).

Economic farm surplus (return before rent and interest) was reduced by $\$ 145,000$, or $\$ 101 /$ ha and by $\$ 209,000$, or $\$ 145 /$ ha from Californian and variegated thistle infestation respectively (Table 7).

\section{Economics of control}

The benefits of thistle control will occur after the control programme has finished and changes on-farm have been made to implement potential changes in stock policy. Therefore, an analysis of the impacts must reflect both the control programme being staged over time, and the future benefits that should accrue. Net present value and potential long-term effects on thistle control were required to better understand the value proposition of control. This was done using an investment framework applying thistle control as an initial capital input (before a standard regime of control), along with capital livestock, as the initial investment. Capital livestock were used as these numbers vary depending on the pasture growth achieved. The economic farm surplus was used as the ongoing income over a 20 -year period, 
and then a net present value was calculated. Net present value was converted to an annuity to represent the relative annual income to test for the long-term impact of thistle control.

Results presented in Table 8 demonstrate the long-term gains made from thistle control, both for variegated and Californian thistles. An increase in annuity of $\$ 119 /$ ha was delivered over the twentyyear period when variegated thistles were controlled. Control of Californian thistles delivered an increase in annuity of $\$ 68 /$ ha above the current estimated returns.

These analyses do not represent the potential costs of transition from the currently modelled status quo situations to a future farm system but do provide insight into what that system might look like, and the potential benefits of change. The annuities returned after thistle control will always be lower that the base model that is weed free. This highlights the benefits of an effective on-going weed control programme.

Previous attempts have been made to demonstrate the impacts of thistles on animal performance (Hartley \& James 1979; Hartley 1983). These studies have highlighted changes in animal performance due to changing pasture utilisation (Hartley \& James 1979) and declining legume content (Hartley 1983). The current approach taken here acknowledges changes in pasture utilisation by using a suppression model which effectively reduces the amount of pasture available per hectare by adjusting for the area of land occupied by the thistle. So while this is expressed as a reduce pasture growth rate, it is effectively a reflection of a reduction in area available for grazing.

A significant issue with thistle control is that it impacts on legume growth (Hartley 1983) and hence animal performance. Growth of browntop pasture with or without legumes were similar at the low Oslen P values. However, some parts of the farm have phosphate levels that would promote legume growth. Therefore, further improvements in both pasture quantity and quality may result from an intensive thistle control programme. This would then require further changes to the livestock enterprises chosen, and further improve whole farm profitability. However, changing legume content, and the subsequent effect on animal growth has not yet been incorporated into a documented farm systems economic model.

\section{Conclusions}

Here we demonstrate that the farm system changes that need to be made to compensate for seasonal changes in pasture growth as a result of infestation with either Californian or variegated thistles are much greater than the total loss of production would suggest. This case study provides evidence that control of annual thistles, which impact on winter and spring pasture growth, is a greater priority for farmers than control of perennial thistles, which affect summer and autumn growth. The use of GIS data to identify slope and aspect, coupled with soil fertility information and site-specific weed information provided a robust platform to estimate the relative impacts of thistle infestation and their control. This approach provides much finer detail and could potentially be used to investigate many scenarios of control across all the defined land management units. This, in turn, would provide farmers with more targeted, cost-effective ways of changing production, profit and environmental outcomes.

\section{ACKNOWLEDGEMENTS}

The authors thank the Tangihanga Station staff for support in data provision, paper review, and on-farm monitoring; the Wi Pere Trust for the opportunity to engage with their farming operations to develop new innovations for the farming community; Ravensdown Ltd for co-funding, support; and the AgResearch SSIF fund for support.

\section{REFERENCES}

Bourdôt GW, Hurrell GA, Trolove M, Saville DJ. 2016. Seasonal dynamics of ground cover in Cirsium arvense - a basis for estimating grazing losses and economic impacts. Weed Research 56: 179-191.

\begin{tabular}{|c|c|c|c|c|c|}
\hline \multirow[t]{2}{*}{ Item } & \multicolumn{4}{|c|}{ Model } & \multirow[b]{2}{*}{$\begin{array}{c}\text { Variegated thistle }+ \\
\text { chemical control }\end{array}$} \\
\hline & Base & $\begin{array}{l}\text { Californian thistle/ } \\
\text { no control }\end{array}$ & $\begin{array}{l}\text { Variegated thistle/ } \\
\text { no chemical control }\end{array}$ & $\begin{array}{l}\text { Californian thistle + } \\
\text { chemical control }\end{array}$ & \\
\hline Stock Capital Value (\$) & $2,581,127$ & $2,191,592$ & $2,293,777$ & $2,581,127$ & $2,581,127$ \\
\hline Area controlled (ha) & 0 & 0 & 0 & 941 & 894 \\
\hline Total control cost (\$) & 0 & 0 & 0 & 335,692 & 263,027 \\
\hline NPV $(\$)$ & $6,480,781$ & $4,919,799$ & $4,055,903$ & $6,145,089$ & $6,198,814$ \\
\hline Annuity (\$/ha) & 361 & 274 & 226 & 342 & 345 \\
\hline
\end{tabular}


Gray MH, Korte CJ, Christieson WM. 1987. Seasonal distribution of pasture production in New Zealand XX. Waerengaokuri (Gisborne). New Zealand Journal of Experimental Agriculture 15: 397-404.

Hartley MJ. 1983. Effect of Scotch thistles on sheep growth rates. Proceedings of the $36^{\text {th }}$ New Zealand Weed and Pest Control Conference: 86-88.

Hartley MJ, James TK. 1979. Cost benefit of Californian thistle control in pasture. Proceedings of the $32^{\text {nd }}$ New Zealand Weed and Pest Control Conference: 245-249.

James TK, Rahman A, Trivedi P. 2010. Germination of seed from five broadleaf weeds after burial for up to 28 years in two soils. New Zealand Plant Protection 63: 84-89.

Keating BA, Carberry PS, Hammer GL, Probert ME, Robertson MJ, Holzworth D, Huth NI, Hargreaves JNG, Meinke H, Hochman Z, McLean G, Verburg K, Snow V, Dimes JP, Silburn M, Wang E, Brown $\mathrm{S}$, Bristow KL, Asseng S, Chapman S, McCown RL, Freebairn DM, Smith CJ. 2003. An overview of APSIM, a model designed for farming systems simulation. European Journal of Agronomy 18: 267288.

Montemurro P, Fracchiolla M, Lonigro A. 2007. Effects of some environmental factors on seed germination and spreading potentials of Silybum marianum Gaertenr. Italian Journal of Agronomy 3: 315-320.

Parmoon G, Moosavi SA, Akbari H, Ebadi A. 2015. Quantifying cardinal temperatures and thermal time required for germination of Silybum marianum seed. The Crop Journal 3: 145-151.

Shea K, Kelly D. 1998. Estimating biocontrol agent impact with matrix models: Carduus nutans in New Zealand. Ecological Applications 8: 824-832.

Shea K, Sheppard A, Woodburn T. 2006. Seasonal lifehistory models for the integrated management of the invasive weed nodding thistle Carduus nutans in Australia. Journal of Applied Ecology 43: 517-526.

Tozer KN, Greenfield RM, Dodd MB, James TK, Cameron CA. 2018. Controlling variegated thistle in east coast North Island hill country. Journal of New Zealand Grasslands 80: 225-233. 
